Article

\title{
FUT2, Secretor Status and FUT3 Polymorphisms of Children with Acute Diarrhea Infected with Rotavirus and Norovirus in Brazil
}

\author{
Marco André Loureiro Tonini ${ }^{1, * \mathbb{C}}$, Débora Maria Pires Gonçalves Barreira ${ }^{1}$, \\ Luciana Bueno de Freitas Santolin ${ }^{1}$, Lays Paula Bondi Volpini ${ }^{1}$, José Paulo Gagliardi Leite ${ }^{2}$, \\ Béatrice Le Moullac-Vaidye ${ }^{3}$, Jacques Le Pendu ${ }^{3}$ and Liliana Cruz Spano ${ }^{1}$ \\ 1 Laboratory of Virology and Infectious Gastroenteritis, Pathology Department, Health Science Center, Federal \\ University of Espírito Santo, Maruípe, Vitória 1468, ES, Brazil; deborambarreira@yahoo.com.br (D.M.P.G.B.); \\ freitas_lb@yahoo.com.br (L.B.d.F.S.); layspaula90@gmail.com (L.P.B.V.); liliana.spano@ufes.br (L.C.S.) \\ 2 Laboratory of Comparative and Environmental Virology, Oswaldo Cruz Institute, \\ Rio de Janeiro 4365, RJ, Brazil; jpgleite@ioc.fiocruz.br \\ 3 CRCINA, Inserm, Université de Nantes, F-44000 Nantes, France; beatrice.vaidye@inserm.fr (B.L.M.-V.); \\ jacques.le-pendu@univ-nantes.fr (J.L.P.) \\ * Correspondence: marco.tonini@ufes.br
}

Received: 23 July 2020; Accepted: 24 September 2020; Published: 25 September 2020

\begin{abstract}
Host susceptibility according to human histo-blood group antigens (HBGAs) is widely known for norovirus infection, but is less described for rotavirus. Due to the variable HBGA polymorphism among populations, we aimed to evaluate the association between HBGA phenotypes (ABH, Lewis and secretor status) and susceptibility to rotavirus and norovirus symptomatic infection, and the polymorphisms of FUT2 and FUT3, of children from southeastern Brazil. Paired fecal-buccal specimens from 272 children with acute diarrhea were used to determine rotavirus/norovirus genotypes and HBGAs phenotypes/genotypes, respectively. Altogether, $100(36.8 \%)$ children were infected with rotavirus and norovirus. The rotavirus $\mathrm{P}[8]$ genotype predominates $(85.7 \%)$. Most of the noroviruses (93.8\%) belonged to genogroup II (GII). GII.4 Sydney represented 76\% (35/46) amongst five other genotypes. Rotavirus and noroviruses infected predominantly children with secretor status ( $97 \%$ and $98.5 \%$, respectively). However, fewer rotavirus-infected children were Lewis-negative $(8.6 \%)$ than the norovirus-infected ones (18.5\%). FUT3 single nucleotide polymorphisms (SNP) occurred mostly at the T59G > G508A > T202C > C314T positions. Our results reinforce the current knowledge that secretors are more susceptible to infection by both rotavirus and norovirus than non-secretors. The high rate for Lewis negative (17.1\%) and the combination of SNPs, beyond the secretor status, may reflect the highly mixed population in Brazil.
\end{abstract}

Keywords: host susceptibility; histo-blood group antigens (HBGAs); norovirus; rotavirus; secretor status; polymorphisms of FUT2 and FUT3; Lewis

\section{Introduction}

Diarrheal diseases remain a leading cause of morbidity and mortality in children under five years of age, and account for nearly 500,000 deaths annually in the world, especially in low-income countries. Enteric viruses, particularly norovirus and rotavirus, are the major etiological agents of diarrhea worldwide [1,2]. Since 2006, two oral, live-attenuated rotavirus vaccines (Rotarix ${ }^{\circledR}$ and RotaTeq ${ }^{\circledR}$ ) have been implemented nationally in 98 countries, and their use has substantially reduced global child deaths from diarrheal illness [3,4]. Nevertheless, the effectiveness of current vaccines is lower in low- 
and middle-income countries compared with higher-income settings [5]. Among other factors, host genetic characteristics have been proposed to explain this difference [6,7].

Rotaviruses are classified into 10 species (A to J), with species A being the major cause of infections in children [8]. Two outer capsid proteins, VP4 (protease-sensitive protein) and VP7 (glycoprotein), are traditionally used to define the rotavirus $\mathrm{P}$ and $\mathrm{G}$ genotypes, respectively. Currently, $36 \mathrm{G}$ and $51 \mathrm{P}$ genotypes have been identified, among which six G genotypes (G1, G2, G3, G4, G9, and G12) and three $\mathrm{P}$ genotypes (P[4], P[6], $\mathrm{P}[8])$ are more prevalent globally [9]. As for noroviruses, they are dually classified based on the complete VP1 (major capsid protein) coding region, corresponding to open reading frame (ORF) 2, and on a partial RNA polymerase (RdRp) coding region located at the $3^{\prime}$-end of the ORF1. Ten norovirus genogroups (GI-GX) are recognized according to the VP1 classification, each being subdivided into genotypes. Genogroups GI and GII that encompass more than 30 genotypes are the main causes of human infection. Among them, the GII.4 genotype is responsible for the majority of norovirus outbreaks and sporadic cases worldwide [10,11]. The $R p R d$ gene classifies noroviruses into eight P-groups and 62 P-types [12].

Both viruses recognize and bind to histo-blood group antigens (HBGAs) which act as host attachment factors for viral infection on enteric epithelial cells [13-15]. Human HBGAs are highly polymorphic carbohydrates expressed on mucosal epithelial cells and the surface of erythrocytes and in biological fluids such as saliva and milk. Their synthesis occurs by the sequential addition of monosaccharides to precursor disaccharides by four major glycosyltransferases: $\alpha-1$, 2-fucosyltransferase (FUT-2), $\alpha-1,3$ fucosyltransferase (FUT3) and A and B enzymes, which are coded by three main HBGA gene families, resulting in $\mathrm{ABO}$ ( $\mathrm{A}, \mathrm{B}$ and/or $\mathrm{H}$ antigens), Lewis (Lewis $\mathrm{a}, \mathrm{b}, \mathrm{x}$ and/or $\mathrm{y}$ antigens) and secretor/non-secretor HBGA phenotypes [16]. The expression of these phenotypes are genetically determined and depend on individual HBGA genotypes, which are influenced by the composition and genetic diversity of the human population [6]. A mutation on both alleles of the FUT2 gene leads to inactivation of the corresponding FUT2 enzyme, and individuals possessing such polymorphism are termed non-secretors. Similarly, individuals with null alleles for the FUT3 gene do not produce Lewis antigens, and are denominated Lewis negative [6].

Genetic susceptibility to norovirus infection mediated by HBGA polymorphisms has been a known phenomenon for decades and, despite solid scientific evidence regarding the association between the norovirus infection, particularly with the predominant GII.4 genotype, and the secretor status, the exact role of the Lewis antigen as a susceptibility mediator remains to be better clarified [17-19].

Less than a decade ago, in vitro studies showing the binding of the VP8* domain of the spike protein VP4 of rotavirus to HBGA paved the way for the development of epidemiological evaluations to understand the effect of HBGA differential expression in susceptibility to rotavirus infection $[14,15]$. These epidemiological studies conducted in different countries including France, Vietnam, Burkina Faso, USA, China, and Spain pointed to the same conclusion that children of the secretor phenotype were significantly more prone to suffer from diarrhea caused by $P[8]$ and $P[4]$ rotavirus compared to the non-secretor [20-25]. However, conflicting results were observed in studies conducted with children from Tunisia, where P[8] strains were found infecting both individuals of secretor and non-secretor phenotypes, and more recently in Bangladesh, where the non-secretor children were not protected from diarrhea caused by the P[8] genotype $[26,27]$. These inconsistencies suggest the need for more epidemiological studies in different populations to better understand the role of HBGA phenotypes in rotavirus infection.

In Brazil, a continental-sized country with a highly genetically admixed population, few studies have analyzed the association between norovirus infection and HBGA phenotypes [28,29] and there are no data yet available regarding rotavirus infection and disease. Therefore, this study aimed to analyze the association between rotavirus and norovirus symptomatic infection and HBGA phenotypes, in addition to FUT2 and FUT3 genes polymorphisms, in children from Southeastern Brazil. In the present study, we were able to reinforce the current knowledge that secretors are more susceptible 
than non-secretors to infection by both rotavirus and norovirus, and that the combination of FUT3 polymorphisms found may reflect the highly mixed Brazilian population.

\section{Materials and Methods}

\subsection{Study Population and Samples}

Fecal and buccal swabs specimens were collected from 272 children up to 12 years old enrolled during a surveillance study of sporadic cases of acute gastroenteritis carried out in two periods (October 2014 to July 2016 and September 2017 to September 2018) in the Southeastern Brazilian coastal state of Espírito Santo. Among these children, 196 (72.1\%) had received rotavirus vaccination, of which 92.9\% (182/196) were fully vaccinated (179 received Rotarix ${ }^{\circledR}$ and three RotaTeq $\left.{ }^{\circledR}\right)$ and the other 14 were partially vaccinated with Rotarix ${ }^{\circledR}$. Twenty-seven $(10 \%)$ children were unvaccinated and for 49 children (18\%) the vaccination status was not available. These children were admitted to a pediatric hospital and an urgent care center situated in the city of Vitória (state capital). During their admission, they were invited to participate in the study and samples were obtained after the signature of a consent form by the person responsible for the patient. The study was approved by the Institutional Research Ethics Committee of the Center of Health Sciences of the Federal University of Espírito Santo $\left(\mathrm{N}^{\circ}\right.$ 1.312.166; 6 November 2015).

The passage of three or more loose or watery stools during a $24 \mathrm{~h}$ period with up to 14 days of duration was considered acute diarrhea [30].

\subsection{Rotavirus and Noroviruses Detection}

Viral RNA was extracted from $10 \%$ fecal suspensions $(w / v)$ using the QIAamp ${ }^{\circledR}$ Viral RNA Mini Kit (QIAGEN, Valencia, CA, USA), according to the manufacturer's instructions. Noroviruses were detected by RT-qPCR using primers and a probe targeting the ORF1/2 junction [31,32]. Rotavirus detection was performed either by an Enzyme immunoassay (ELISA) (Ridascreen ${ }^{\circledR}$, R-Biopharm, Darmstadt, Germany), according to the manufacturer's recommendation, or by RT-qPCR, with primers and a probe specific to amplifying a conserved region of the non-structural protein 3 gene (NSP3) of the virus [33].

\subsection{Rotavirus P Typing and Noroviruses Genotyping}

Rotavirus $\mathrm{P}$ types were determined from positive samples with specific primers for a fragment of the VP4 gene, followed by sequencing [34]. For noroviruses genotyping, positive samples were initially amplified by PCR using a set of primers targeting a $570 \mathrm{bp}$ fragment encompassing the $3^{\prime}$-end ORF1 and $5^{\prime}$-end ORF2 and then sequenced [35,36]. Sequencing for both viruses was carried out with ABI Prism Big Dye Terminator v3.1 Cycle Sequencing Ready Reaction Kit on an ABI Prism 310 Genetic Analyzer (Applied Biosystems, Foster City, CA, USA). The noroviruses' genotype was ascribed using the Norovirus Automated Genotyping Tool version 2.0, (https://www.rivm.nl/mpf/typingtool/norovirus/) [37]. The 33 VP4 sequences of rotavirus were deposited on GenBank under the accession numbers MT597424 and MT602430-MT602461. As to norovirus, the 46 ORF-1/2 sequences were deposited on GenBank under the accession numbers KY451971-KY451984, MF158177-MF158179, MF158185-MF158199 [38], MT613346-MT613358, and MT626025.

\subsection{Histo-Blood Group Antigens Phenotyping}

HBGAs phenotypes were determined from buccal swabs specimens by enzyme-linked immunosorbent assay (ELISA), as described elsewhere [39]. Buccal swabs immersed in phosphate-buffered saline (PBS) were first boiled for $10 \mathrm{~min}$, and then used at a dilution of 1:50 in a $0.1 \mathrm{M}$ carbonate/bicarbonate buffer ( $\mathrm{pH}$ 9.6) to coat 96-well microtiter plates (Maxisorp Nunc-Immuno plates, Thermo Scientific, Roskilde, Denmark), which were then incubated overnight at $4{ }^{\circ} \mathrm{C}$. The plates were washed three times with PBS containing $0.05 \%$ Tween-20, and blocked with PBS containing 5\% nonfat milk (5\% milk/PBS) for $1 \mathrm{~h}$ at 
$37^{\circ} \mathrm{C}$. Primary anti-carbohydrate monoclonal antibodies anti-A (3-3A), anti-B (B49), anti-Le ${ }^{\text {a }}$ (7LE) and anti-Le ${ }^{\mathrm{b}}$ (2-25LE) (Thermo Scientific) diluted at 1:400 in 5\% milk/PBS were added and incubated for $1 \mathrm{~h}$ at $37^{\circ} \mathrm{C}$. At this step, the lectin UEA-1 ("Ulex Europaeus Agglutinin I"-Vector Laboratories, Burlingame, CA, USA) conjugated with biotin was also used to detect the $\mathrm{H}$ antigen. After three washes, peroxidase-conjugated anti-mouse immunoglobulin diluted at 1:2000 in 5\% milk/PBS and peroxidase-conjugated Streptavidin (Vector Laboratories) diluted at 1:500 in 5\% milk/PBS were then added and incubated for $1 \mathrm{~h}$ at $37^{\circ} \mathrm{C}$. After the last three washes, reactions were developed with a $3,3^{\prime}$, 5, 5'-Tetramethylbenzidine kit (BD OptEIA, BD Biosciences, San Jose, CA, USA), and the optical density was read at $450 \mathrm{~nm}$. Previously well-defined A, B, O, secretor, and Lewis type saliva samples were included in each plate as controls. The cutoff value was defined as a twofold increase in absorbance value compared to the mean of two negative control samples (wells with only PBS). The distribution of $\mathrm{ABO}$ blood groups, $\mathrm{H}$ type 1 antigen (FUT-2), and Lewis antigens were determined between diarrheic children of the same ages and geographic area infected and non-infected by rotavirus and norovirus.

\subsection{FUT2 and FUT3 Genotyping}

Single nucleotide polymorphisms (SNPs) in the FUT2 and FUT3 genes were investigated as described below. Genomic DNA from buccal swabs specimens was extracted with the NucleoSpin ${ }^{\circledR}$ Tissue kit (Macherey-Nagel, Düren, Germany), according to the manufacturer's instructions. For FUT2 genotyping, a 195 bp FUT2 gene fragment was initially amplified by PCR and then digested with the enzyme Ava-II, as previously described [39]. This method enables detection of the common G428A FUT2 mutation as it abrogates the restriction site of the enzyme. For genotyping of the Lewis (FUT3) gene mutations, four gene fragments encompassing the worldwide common mutations C314T, G508A, and T1067A were amplified by real-time PCR and submitted to Sanger DNA sequencing, except for mutations T59G and T202C, which were searched for by conventional PCR using sequence-specific primers [40]. For the latter two mutations, a human growth hormone $(h G H)$ gene amplification was performed as an internal control in each round of PCR [41]. The FUT3 sequences involving the C314T/G508A mutations were deposited on GenBank under the accession numbers MT656016-MT656059 and the FUT3 sequences encompassing T1067A mutation were deposited on GenBank under the accession numbers MT725617-MT725659.

\subsection{Statistical Analysis}

Analysis of categorical data was done with the Fisher exact test, with two-tailed significance using the GraphPad software. A $p$ value lower than 0.05 was considered statistically significant.

\section{Results}

\subsection{Rotavirus and Noroviruses Detection on Children with Acute Diarrhea}

Of the 272 children presenting acute diarrhea, 35 (12.9\%) and $65(23.9 \%)$ had rotavirus and norovirus infections, respectively (Table 1). Rotavirus and norovirus coinfection was detected in only one child. The age distribution of rotavirus and noroviruses infection can be observed in Table 1.

Table 1. Distribution of children infected with rotavirus and noroviruses according to age groups.

\begin{tabular}{ccccc}
\hline Age & Number of Samples $\boldsymbol{N}(\mathbf{\%})$ & Rotavirus+ $\boldsymbol{N}(\mathbf{\%})$ & Norovirus+ $\boldsymbol{N}(\mathbf{\%})$ & Negative $\boldsymbol{N}(\mathbf{\%})$ \\
\hline$\leq 12 \mathrm{~m}$ & $99(36.4)$ & $9(9.1)$ & $33(33.3)$ & $57(57.6)$ \\
$>12 \mathrm{~m}-2 \mathrm{y}$ & $78(28.7)$ & $9(11)$ & $20(25)$ & $50(64)$ \\
$>2-5 \mathrm{y}$ & $61(22.4)$ & $13(21.3)$ & $9(14.7)$ & $39(64)$ \\
$>5 \mathrm{y}$ & $34(12.5)$ & $5(14.7)$ & $3(8.8)$ & $26(76.5)$ \\
\hline Total & 272 & $35(12.9)$ & $65(23.9)$ & $172(63.2)$ \\
\hline
\end{tabular}

Abbreviations: m, months; y, years; Rotavirus+, rotavirus infected children; Norovirus+, norovirus infected children. 


\subsection{Rotavirus and Noroviruses Genotyping}

The $\mathrm{P}[8]$ genotype predominated $(30 / 35 ; 85.7 \%)$ among the rotavirus positive samples, while two (5.7\%) belonged to the $\mathrm{P}[4]$ genotype and three was $\mathrm{P}[\mathrm{X}]$. All the $\mathrm{P}[8]$ strains belonged to lineage 3.

Sixty-one out of 65 (93.8\%) positive samples for noroviruses belonged to GII, $4.6 \%$ to GI, and in one sample (1.5\%), both GI and GII were detected. Genotypes were successfully established for 46 samples, and the majority (76\%) was represented by the GII.4 Sydney variant (Table 2).

Table 2. Noroviruses VP1 gene genotyping.

\begin{tabular}{cc}
\hline VP1 & Strains $\mathbf{N ~ ( \% )}$ \\
\hline GI.7 & $1(2.2)$ \\
GII.4 Sydney & $35(76)$ \\
GII.17 & $5(10.9)$ \\
GII.3 & $2(4.3)$ \\
GII.1 & $1(2.2)$ \\
GII.2 & $1(2.2)$ \\
GII.6 & $1(2.2)$ \\
\hline
\end{tabular}

\subsection{HBGA Phenotypes among Rotavirus and Norovirus Infected Children}

Rotavirus predominantly infected children with secretor status $(34 / 35 ; 97 \%)$. The only non-secretor infected child was infected by a P [8] strain. In comparison, $82 \%$ (141) of the negative group, which was used as a control group, were secretors, and $18 \%$ (31) were non-secretors ( $p=0.0207)$ (Table 3). There was no statistical difference between the distribution of Lewis status and ABO blood types among rotavirus infected children compared to the control group (Table 3). Although we observed a lower frequency of Lewis negative children in the infected group as compared with the control group $(8.6 \%$ vs. $18.5 \%)$, the difference was not statistically significant, likely owing to the limited number of cases.

Table 3. Distribution of histo-blood group antigens (HBGAs) phenotypes between children infected with rotavirus/noroviruses and the negative control group.

\begin{tabular}{|c|c|c|c|c|c|c|}
\hline \multirow{2}{*}{ HBGA Phenotype } & \multirow{2}{*}{ Total N (\%) } & \multirow{2}{*}{$\begin{array}{l}\text { Rotavirus+ } \\
\quad N(\%)\end{array}$} & \multirow{2}{*}{$\begin{array}{c}\text { Norovirus+ } \\
\quad N(\%)\end{array}$} & \multirow{2}{*}{$\begin{array}{l}\text { Negative Control } \\
\text { Group } N(\%)\end{array}$} & \multicolumn{2}{|c|}{$p$ Value } \\
\hline & & & & & Rotavirus+ & Norovirus+ \\
\hline \multicolumn{7}{|l|}{ Secretor status: } \\
\hline Se & 239 (87.9) & $34(97)$ & $64(98.5)$ & $141(82)$ & \multirow{2}{*}{0.0207} & \multirow{2}{*}{0.0004} \\
\hline se & $33(12.1)$ & $1(3)$ & $1(1.5)$ & $31(18)$ & & \\
\hline \multicolumn{7}{|l|}{ Lewis phenotype: } \\
\hline $\mathrm{Le}^{+}$ & 225 (82.5) & $32(91.4)$ & $53(81.5)$ & $140(81.4)$ & \multirow{2}{*}{0.2154} & \multirow{2}{*}{1.0000} \\
\hline $\mathrm{Le}^{-}$ & $47(17.1)$ & $3(8.6)$ & $12(18.5)$ & $32(18.6)$ & & \\
\hline \multicolumn{7}{|l|}{ Blood groups: } \\
\hline $\mathrm{O}$ & $128(53.6)$ & $15(44)$ & $39(61)$ & $74(52.5)$ & \multirow{4}{*}{0.4464} & \multirow{4}{*}{0.2907} \\
\hline A & $72(30.1)$ & $11(32.4)$ & $19(29.7)$ & $42(29.8)$ & & \\
\hline B & $31(13)$ & $6(17.6)$ & $4(6.2)$ & $21(14.9)$ & & \\
\hline $\mathrm{AB}$ & $8(3.3)$ & $2(6)$ & $2(3.1)$ & $4(2.8)$ & & \\
\hline
\end{tabular}

Abbreviations: $\mathrm{Le}^{+}$, Lewis-positive (Lewis a and/or b positive); $\mathrm{Le}^{-}$, Lewis-negative (Lewis a and $\mathrm{b}$ negative); Norovirus+, norovirus infected children; Rotavirus+, rotavirus infected children; Se, secretor; se, non-secretor.

The HBGA secretor phenotype was observed in 64 out of 65 (98.5\%) children infected with norovirus, and one infected child (1.5\%) had the non-secretor phenotype. Conversely, in the negative control group, 31 out of $172(18 \%)$ children were non-secretors and the difference between the number of non-secretors in cases and controls was statistically significant $(p=0.0004)$ (Table 3$)$. There was no difference in the distribution of $\mathrm{ABO}$ blood groups and Lewis status between the norovirus infected individuals and the control group (Table 3). Analysis of HBGA phenotypes stratified by norovirus genotypes showed that all 35 GII.4 strains infected only children with secretor status, and the non-secretor patient was infected by a GII.3 strain (Table 4). The three GI viruses infected the secretor 
Lewis-positive children, whereas the GII genogroup infected both the secretor Lewis-negative and Lewis-positive children (Table 4).

Table 4. Distribution of histo-blood group antigen phenotypes in relation to noroviruses genogroup and genotypes among children infected with noroviruses in Espírito Santo state, Brazil.

\begin{tabular}{|c|c|c|c|c|c|c|c|c|c|c|}
\hline $\begin{array}{c}\text { Norovirus } \\
\text { Genogroup/Genotype }\end{array}$ & $N$ & \multicolumn{4}{|c|}{ Blood Groups } & \multicolumn{3}{|c|}{ Lewis Phenotypes } & \multicolumn{2}{|c|}{ Secretor Status } \\
\hline G.I* & 3 & 1 & 1 & 1 & - & 3 & - & - & 3 & - \\
\hline G.II & 61 & 39 & 15 & 4 & 2 & 50 & 10 & 1 & 60 & 1 \\
\hline GII.1 & 1 & 1 & - & - & - & 1 & - & - & 1 & - \\
\hline GII.2 & 1 & 1 & - & - & - & 1 & - & - & 1 & - \\
\hline GII.6 & 1 & - & 1 & - & - & 1 & - & - & 1 & - \\
\hline GII.17 & 5 & 2 & 3 & - & - & 3 & 2 & - & 5 & - \\
\hline GII * & 16 & 11 & 1 & 3 & 1 & 16 & - & - & 16 & - \\
\hline G.I and G.II & 1 & - & 1 & - & - & - & 1 & - & 1 & - \\
\hline
\end{tabular}

Abbreviations: $\mathrm{Le}^{\mathrm{a}-\mathrm{b}+}$, Lewis a negative and Lewis $\mathrm{b}$ positive; Le $\mathrm{e}^{\mathrm{a}-\mathrm{b}-}$, Lewis-negative (Lewis a and $\mathrm{b}$ negative); $\mathrm{Le}^{\mathrm{a}+\mathrm{b}-}$, Lewis a positive and Lewis $\mathrm{b}$ negative. ${ }^{*}$ Refers to strains with undetermined genotypes.

\subsection{FUT2 and FUT3 Genotyping}

Secretor and non-secretor phenotypes determined by ELISA for both the rotavirus and norovirus infected and the negative control groups were confirmed by FUT2 genotyping based on the G428A mutation. All non-secretors $(N=33)$ from both the infected and negative groups were homozygous carriers of the FUT2 G428A nonsense mutation (Table 5). The difference in the number of patients with the non-secretor genotype $\left(\mathrm{se}^{428} / \mathrm{se}^{428}\right)$ among the rotavirus/norovirus infected groups compared to the negative control group was statistically significant (rotavirus: $p=0.0207$; norovirus: $p=0.0004$ ) (Table 5).

Table 5. Distribution of FUT-2 genotypes among infected patients and controls according to G428A mutation.

\begin{tabular}{|c|c|c|c|c|c|c|}
\hline FUT-2 Genotype & Total N (\%) & $\begin{array}{l}\text { Rotavirus+ } \\
\quad N(\%)\end{array}$ & $\begin{array}{l}\text { Norovirus+ } \\
\quad N(\%)\end{array}$ & $\begin{array}{l}\text { Negative Control } \\
\text { Group N (\%) }\end{array}$ & \multicolumn{2}{|c|}{$p$ Value } \\
\hline SE/SE & $99(36.4)$ & $11(31.4)$ & $33(50.8)$ & $55(32)$ & & \\
\hline $\mathrm{SE} / \mathrm{se}^{428}$ & $140(51.5)$ & $23(65.7)$ & 31 (47.7) & $86(50)$ & 0.0207 & 0.0004 \\
\hline $\mathrm{se}^{428} / \mathrm{se}^{428}$ & 33 (12.1) & $1(2.9)$ & $1(1.5)$ & $31(18)$ & & \\
\hline
\end{tabular}

Abbreviations: FUT-2, fucosyltransferase 2 gene; SE/SE, homozygote secretor; SE/se ${ }^{428}$, heterozygote secretor; $\mathrm{se}^{428} / \mathrm{se}^{428}$, non-secretor genotype; Norovirus+, norovirus infected children; Rotavirus+, rotavirus infected children.

To confirm the Lewis-negative phenotype (Le a and b negative), all 47 samples from children with this phenotype were submitted to FUT3 gene genotyping, which included the analysis of the common SNPs T59G, T202C, C314T, G508A, and T1067A, and 45 of them were genotypically confirmed as Lewis negative. The most common polymorphism was the T59G with an overall frequency of $86.6 \%$ (39/45), followed by the G508A, T202C and C314T SNPs with frequencies of 77.2\%, 53.3\% and 50\%, respectively (Table 6). By contrast, the T1067A SNP was the rarest, with a frequency of $4.6 \%(2 / 43)$, including one homozygote and one heterozygote (Table 6). The frequencies of all SNP analyzed for the FUT3 gene are shown in Table 7. The two samples with undetermined Lewis genotype had only one heterozygote allele among the investigated mutations. Homozygotes alleles for more than one of the T59G, T202C, C314T, G508A, T1067A mutations were observed in eight individuals, and there were also eight homozygotes for only one mutation. The remaining 29 patients were heterozygote for at least two of the evaluated mutations (Table 7). 
Table 6. Frequencies of polymorphisms on FUT-3 gene in Lewis negative children.

\begin{tabular}{ccccc}
\hline \multirow{2}{*}{ SNP } & \multicolumn{4}{c}{ Frequency, $\mathbf{N}(\%)$} \\
\cline { 2 - 5 } & Mutant Homozygotes & Heterozygotes & Wild Type Homozygotes & Total \\
\hline G508A & $10(22.7)$ & $24(54.6)$ & $10(22.7)$ & $44^{\text {a }}$ \\
\hline T59G & $8(17.8)$ & $31(68.9)$ & $6(13.3)$ & 45 \\
\hline T202C & $3(6.6)$ & $21(46.7)$ & $21(46.7)$ & 45 \\
\hline C314T & $2(4.5)$ & $20(45.5)$ & $22(50)$ & $44^{\text {a }}$ \\
\hline T1067A & $1(2.3)$ & $1(2.3)$ & $41(95.4)$ & $43^{\text {a }}$ \\
\hline
\end{tabular}

Abbreviations: SNP, single nucleotide polymorphism. ${ }^{\text {a }}$ One sequence for one patient for mutations G508A and C314T, and two sequences for T1067A could not be determined.

Table 7. FUT3 alleles frequencies observed in South-eastern Brazilian children.

\begin{tabular}{cc}
\hline FUT3 Allele & Frequency, $N$ (\%) \\
\hline Lele $e^{59,202,314,508}$ & $13(31)$ \\
Lele $e^{59,508}$ & $11(26)$ \\
Lele 202,314 & $4(9.5)$ \\
Lele ${ }^{59,202,314,1067}$ & $1(2.4)$ \\
Lele $l 59,202,314$ & $1(2.4)$ \\
Lele $e^{59,202}$ & $1(2.4)$ \\
$l e^{508} l e^{59,508}$ & $5(11.9)$ \\
$l e^{59} l e^{59,508}$ & $2(4.8)$ \\
$l e^{59,1067} l e^{59,202,1067}$ & $1(2.4)$ \\
$l e^{202} l e^{59,202,314}$ & $1(2.4)$ \\
$l e^{59,508} l e^{59,508}$ & $1(2.4)$ \\
$l e^{202,314} l e^{202,314}$ & $1(2.4)$ \\
\hline eviations: Le, Lewis wild-type allele; $l e$, Lewis mutant allele.
\end{tabular}

\section{Discussion}

The interaction of rotavirus with HBGA has gained importance in the last years, with the discovery of VP8* binding to these glycans [14,15]. Studies have shown that this interaction is P genotypespecific, similar to that observed for VP1 of human noroviruses, and that the susceptibility or resistance to both viruses is largely dependent on the presence or absence of HBGA on gut epithelial surfaces. In addition, the association between the secretor status and infection, initially demonstrated for noroviruses, has also been shown by recent studies for rotavirus, which has demonstrated a correlation between infection and the presence of a functional FUT2 phenotype [23,42-44].

In this study, we have shown the association between the HBGA secretor status and rotavirus and noroviruses infection in Brazilian children, a finding that is consistent with previous epidemiological investigations worldwide [18,20-25]. Our data add further support to this notion and contribute to the understanding of this association in a highly mixed population like the Brazilian one.

Due to the circulation of emerging P[8]-4 strains [45] with distinct glycan-binding patterns that allow non-secretors to be more prone to infection [46], we searched for possible mutations on the VP8* glycan-binding amino acid sequence of the $\mathrm{P}[8]$ strain that infected the non-secretor patient in our study. The analysis of the patient's VP8* P[8], as well as of the other P[8] strains (all classical P[8]-3 strains) detected in the study, did not demonstrate variations both on conserved and non-conserved residues, compared to other classical P[8] strains detected in the world. Thus, variations on VP8* could not explain the patient's infection. One hypothesis is that this child was poorly immunized, possibly in part because of his HBGA status (non-secretor), and also because he received only one dose of the Rotarix ${ }^{\circledR}$ vaccine. Later on, the patient may have ingested a large dose of the virus and became ill. We are not dealing with an all or nothing phenomenon and amounts likely matter. This could well be a difference between countries or regions concerning the quality of sanitation and hygiene. 
$\mathrm{P}[8]$ and $\mathrm{P}[4]$ rotavirus genotypes cause more than $90 \%$ of the pediatric diarrhea cases in the world, including in Brazil [47]. These data are consistent with those observed in the present study in which all the rotavirus detected belonged to these two genotypes. The fact that $\mathrm{P}[8]$ and $\mathrm{P}[4]$ genotypes recognize $\mathrm{Le}^{\mathrm{b}}$ and $\mathrm{H}$ type 1 antigens, expressed only in secretor individuals, may explain the worldwide predominance of these genotypes $[24,48]$. Although the frequency of the secretor phenotype varies across populations, approximately $80 \%$ of the world population are secretors [16]. In Brazil, the prevalence of this phenotype revealed in the few studies, is somewhat similar, ranging from $75 \%$ to $90 \%$ [28,49-51]. The $82 \%$ of secretors in the control group found in the present study were therefore consistent with these previous observations. The most common FUT2 mutation, G428A, was observed in all non-secretor children in our study, which contrasts with a recent study performed in North of South America with Amazonian children from Brazil, Venezuela, and English Guyana, where this common FUT2 gene mutation was not detected [50]. These results highlight the importance of studying the influence of FUT2 polymorphisms on susceptibility to enteric viruses in populations of different geographic locations, such as those from Latin America.

Apart from studying the susceptibility to natural rotavirus infection, some studies have been focused on the role of HBGA on the rotavirus vaccine response. In this regard, some argue that the differential efficacy of the two main rotavirus vaccines (Rotarix ${ }^{\circledR}$ and RotaTeq ${ }^{\circledR}$ ) between low-income and high-income countries may be linked to the different HBGA expression in the population. Indeed, higher vaccine take has been observed in children with the secretor phenotype, compared to non-secretors $[43,52,53]$. Interestingly, in a recent study assessing the association of rotavirus shedding and the HBGA profile in a birth community-cohort in Rio de Janeiro, Brazil, a mutation in the 167 position of the VP8* $\mathrm{P}$ [8] gene was detected in many samples characterized as Rotarix ${ }^{\circledR}$ strain (RV1) [54]. Moreover, $\mathrm{Le}^{\mathrm{a}+\mathrm{b}+}$ secretor children were significantly more likely to shed this mutant strain compared to non-secretors. Based on these results, it was suggested that the RV1-vaccine replication triggered by this mutational event led to a more robust immune response in these children [54].

In our study, the majority (72\%) of the children were vaccinated against rotavirus, particularly with Rotarix ${ }^{\circledR}$, and this may be considered as introducing a bias, since one may expect non-secretors to be less well vaccinated than secretors. However, rotavirus infected children are still mostly secretors indicating that no such bias occurred, either the secretor status may not have been an important factor in determining vaccine efficacy, or that the most important factor is the genetic susceptibility at the time of infection.

The globally predominant norovirus genotype GII.4, detected in most of our samples (76\%), infected only children with the secretor phenotype. These results further confirm the secretor specificity of the GII.4 genotype previously observed through epidemiological studies conducted in different countries such as Burkina Faso, China, Ecuador, USA, Nicaragua, and Vietnam [18,21,55-58]. Furthermore, among the GII.4, all belonged to the GII.4 Sydney variant which has already been shown to be secretor-specific [18]. Although still unclear, the reasons for the global dominance of GII.4 are at least partially linked to its HBGA-binding characteristics. GII.4 strains bind to glycans of all secretor-positive individuals, irrespective of their $\mathrm{ABO}$ and Lewis phenotypes. Moreover, as previously suggested, an increased affinity of HBGA to some of the more recent GII. 4 variants may have contributed to the epidemiological dominance of these variants [59]. It is conceivable that these features, in addition to the high prevalence of secretor-positive individuals in the world population, would provide a broad spectrum of susceptible hosts worldwide and affect GII.4 infection.

Regarding the non-GII.4 norovirus genotypes, all but one was found among the infected secretorpositive children, although we detected GII.1 and GII.2 genotypes capable of infecting non-secretors to a similar extent as secretors [57,60]. The only non-secretor child was infected with the GII.3 norovirus genotype. In fact, this genotype has been reported to infect both secretors and non-secretors, and although some studies indicate that the secretors are more prone to infection by that genotype, the association is not as strong as that observed for the GII.4 genotype [21,61]. 
We observed a trend towards the occurrence of rotavirus infection on secretor Lewis positive children $(91.4 \%)$, without reaching statistical significance, probably due to the low number of rotavirus cases. This result is similar to that obtained in an epidemiological study conducted in Burkina Faso and Nicaragua that showed that no secretor/Lewis negative child with diarrhea was infected by P[8] [22]. Moreover, previous studies suggest that both the Lewis $b$ and secretor antigens are required for $P[8]$ and P[4] VP8* binding $[24,48,62]$. On the other hand, recent structural studies involving P[8] VP8* binding to HBGA presented conflicting results. While some indicate the additional fucose conferred by the Lewis $b$ antigen would cause steric hindrance to the interaction, other studies demonstrated binding of $\mathrm{P}[8] \mathrm{VP} 8^{*}$ to the Lewis $\mathrm{b}$ antigen via a pocket formed by two $\beta$-sheets [63-65]. Further studies are warranted to clarify this issue.

Overall, the results of the Lewis phenotyping revealed that the Lewis status (positive/negative) is not a mediator of susceptibility to norovirus infection, an observation consistent with previous studies $[55,58,66]$. Nevertheless, one study from Taiwan observed that the Lewis antigen-positive genotype was a protective factor against severe norovirus gastroenteritis [67]. In addition, while the three norovirus GI infected only Lewis-positive children, the norovirus GII infected both Lewis-negative and Lewis-positive children, similar to previous findings from Burkina Faso [55]. In favor of the GI's preference to infect Lewis-positive individuals, Kubota and colleagues demonstrated a structural basis for the recognition of Lewis antigens by the GI norovirus [68]. Unfortunately, due to the limited number of GI positive samples, we could not evaluate the Lewis effect for individual genotypes.

The frequency of $17.1 \%$ of Lewis-negative individuals observed in the present study is higher than that registered in people of European descent such as in Scandinavia (5.7\%), Spain (6\%), and Portugal $(10 \%)[25,66,69]$. Nevertheless, the frequency of this phenotype in the highly mixed Brazilian population is similar to other countries of the American continent including Colombia (22\%) and Nicaragua $(25 \%)$, and can reach up to $32 \%$ in some African populations [22,58,70]. Among the Lewis negative individuals, four main SNP were identified at positions T59G, G508A, T202C, and C314T. These results are in agreement with a study conducted with an Amazonian population, and a recent birth community-cohort in Rio de Janeiro, in which these SNPs were detected with similar frequencies [29,71]. In addition, the combination of SNPs found in the present study are also known to occur in Asian, African, and European populations, with the T59G and G508A being more frequent in the first two continents, and the T202C and C314T in the latter [72-74].

\section{Conclusions}

Our findings add to the existing knowledge that children with an FUT2 secretor status are indeed more susceptible to both rotavirus and norovirus symptomatic infection, compared to non-secretors, and contribute to improving the understanding of the host susceptibility to these viruses and their epidemiology in Latin America. Moreover, the high rate for Lewis negative and the combination of SNPs, beyond the secretor status, may reflect the highly mixed population from Brazil, and, to some extent, restrict the infection by rotavirus but not by norovirus. New studies in populations with distinct ethnicities from Brazil and other countries of the South American continent are still warranted to better evaluate the impact of FUT2 and FUT3 polymorphisms on rotavirus and norovirus susceptibility.

Author Contributions: Conceptualization, L.C.S., J.P.G.L. and J.L.P.; methodology, L.C.S., M.A.L.T., D.M.P.G.B., L.B.d.F.S., L.P.B.V., B.L.M.-V. and J.L.P.; formal analysis, L.C.S., M.A.L.T., D.M.P.G.B., L.B.d.F.S., L.P.B.V. and B.L.M.-V.; investigation, M.A.L.T., D.M.P.G.B., B.L.M.-V., L.B.d.F.S. and L.P.B.V.; data curation, L.C.S., M.A.L.T., D.M.P.G.B. and J.L.P.; writing—original draft preparation, L.C.S. and M.A.L.T.; writing—review and editing, L.C.S., M.A.L.T., J.P.G.L. and J.L.P.; supervision, L.C.S. and J.L.P.; project administration, L.C.S.; funding acquisition, L.C.S. All authors have read and agreed to the published version of the manuscript. 
Funding: This research was funded by Espírito Santo Research Foundation (FAPES)/National Council for Scientific and Technological Development (CNPq)/Department of Science and Technology (Decit)-Secretary of Science Technology and Strategic Inputs (SCTIE) - Health Ministry (MS)/Health's Secretary (SESA) (no. 65711670-2014 PPSUS). This study was also financed in part by the Coordenação de Aperfeiçoamento de Pessoal de Nível Superior-Brazil (CAPES)-Finance Code 001.

Acknowledgments: We are grateful to Lucas Luis Meigre Dias Pereira, Núbia Gonçalves, Thainá Bezerra Rubens and Willamis Soares Franqueta for helping during sample collection and laboratory analysis.

Conflicts of Interest: The authors declare no conflict of interest.

\section{References}

1. GBD 2016 Diarrhoeal Disease Collaborators. Estimates of the global, regional, and national morbidity, mortality, and aetiologies of diarrhoea in 195 countries: A systematic analysis for the global burden of disease study 2016. Lancet Infect. Dis. 2018, 18, 1211-1228.

2. Troeger, C.; Khalil, I.A.; Rao, P.C.; Cao, S.; Blacker, B.F.; Ahmed, T.; Armah, G.; Bines, J.E.; Brewer, T.G.; Colombara, T.V.; et al. Rotavirus vaccination and the global burden of rotavirus diarrhea among children younger than 5 years. JAMA Pediatrics 2018, 172, 958-965. [PubMed]

3. Burnett, E.; Jonesteller, C.L.; Tate, J.E.; Yen, C.; Parashar, U.D. Global impact of rotavirus vaccination on childhood hospitalizations and mortality from diarrhea. J. Infect. Dis. 2017, 215, 1666-1672. [PubMed]

4. International Vaccine Access Center (IVAC). Johns Hopkins Bloomberg School of Public Health. Available online: http://www.view-hub.org/viz/ (accessed on 12 February 2020).

5. Jonesteller, C.L.; Burnett, E.; Yen, C.; Tate, J.E.; Parashar, U.D. Effectiveness of rotavirus vaccination: A systematic review of the first decade of global postlicensure data, 2006-2016. Clin. Infect. Dis. 2017, 65, 840-850.

6. Le Pendu, J.; Ruvoën-Clouet, N. Fondness for sugars of enteric viruses confronts them with human glycans genetic diversity. Hum. Genet. 2019, 1-8. [CrossRef]

7. Velasquez, D.E.; Parashar, U.; Jiang, B. Decreased performance of live attenuated, oral rotavirus vaccines in low-income settings: Causes and contributing factors. Expert Rev. Vaccines 2018, 17, 145-161.

8. International Committee on Taxonomy of Viruses (ICTV). Available online: https://talk.ictvonline.org/ taxonomy/ (accessed on 9 May 2020).

9. Rotavirus Classification Working Group (RCWG). Available online: https://rega.kuleuven.be/cev/viralmetagenomics/ virus-classification/rcwg (accessed on 5 February 2020).

10. Mans, J. Norovirus infections and disease in lower-middle and low-income countries, 1997-2018. Viruses 2019, 11, 341. [CrossRef]

11. Parra, G.I. Emergence of norovirus strains: A tale of two genes. Virus Evol. 2019, 5. [CrossRef]

12. Chhabra, P.; de Graaf, M.; Parra, G.I.; Chan, M.C.-W.; Green, K.; Martella, V.; Wang, Q.; White, P.A.; Katayama, K.; Vennema, H.; et al. Updated classification of norovirus genogroups and genotypes. J. Gen. Virol. 2019, 100, 1393-1406.

13. Marionneau, S.; Ruvoen, N.; Le Moullac-Vaidye, B.; Clement, M.; Cailleau-Thomas, A.; Ruiz-Palacois, G.; Huang, P.; Jiang, X.; Le Pendu, J. Norwalk virus binds to histo-blood group antigens present on gastroduodenal epithelial cells of secretor individuals. Gastroenterology 2002, 122, 1967-1977.

14. Hu, L.; Crawford, S.E.; Czako, R.; Cortes-Penfield, N.W.; Smith, D.F.; Le Pendu, J.; Estes, M.K.; Prasad, B.V. Cell attachment protein VP8* of a human rotavirus specifically interacts with a-type histo-blood group antigen. Nature 2012, 485, 256-259. [CrossRef]

15. Huang, P.; Xia, M.; Tan, M.; Zhong, W.; Wei, C.; Wang, L.; Morrow, A.; Jiang, X. Spike protein VP8* of human rotavirus recognizes histo-blood group antigens in a type-specific manner. J. Virol. 2012, 86, 4833-4843. [CrossRef] [PubMed]

16. Le Pendu, J.; Nyström, K.; Ruvoën-Clouet, N. Host-pathogen co-evolution and glycan interactions. Curr. Opin. Virol. 2014, 7, 88-94. [CrossRef]

17. Thorven, M.; Grahn, A.; Hedlund, K.O.; Johansson, H.; Wahlfrid, C.; Larson, G.; Svensson, L. A homozygous nonsense mutation (428G->A) in the human secretor (FUT2) gene provides resistance to symptomatic norovirus (GGII) infections. J. Virol. 2005, 79, 15351-15355. [CrossRef] [PubMed] 
18. Currier, R.L.; Payne, D.C.; Staat, M.A.; Selvarangan, R.; Shirley, S.H.; Halasa, N.; Boom, J.A.; Englund, J.A.; Szilagyi, P.G.; Harrison, C.J.; et al. Innate susceptibility to norovirus infections influenced by FUT2 genotype in a United States pediatric population. Clin. Infect. Dis. 2015, 60, 1631-1638. [CrossRef] [PubMed]

19. Nordgren, J.; Svensson, L. Genetic susceptibility to human norovirus infection: An update. Viruses 2019, 11, 226. [CrossRef]

20. Imbert-Marcille, B.M.; Barbé, L.; Dupé, M.; Le Moullac-Vaidye, B.; Besse, B.; Peltier, C.; Ruvoën-Clouet, N.; Le Pendu, J. A FUT2 gene common polymorphism determines resistance to rotavirus a of the P [8] genotype. J. Infect. Dis. 2014, 209, 1227-1230. [CrossRef] [PubMed]

21. Van Trang, N.; Vu, H.T.; Le, N.T.; Huang, P.; Jiang, X.; Anh, D.D. Association between norovirus and rotavirus infection and histo-blood group antigen types in Vietnamese children. J. Clin. Microbiol. 2014, 52, 1366-1374. [CrossRef]

22. Nordgren, J.; Sharma, S.; Bucardo, F.; Nasir, W.; Günaydın, G.; Ouermi, D.; Nitiema, L.W.; Becker-Dreps, S.; Simpore, J.; Hammarström, L.; et al. Both Lewis and secretor status mediate susceptibility to rotavirus infections in a rotavirus genotype-dependent manner. Clin. Infect. Dis. 2014, 59, 1567-1573. [CrossRef]

23. Payne, D.C.; Currier, R.L.; Staat, M.A.; Sahni, L.C.; Selvarangan, R.; Halasa, N.B.; Englund, J.A.; Weinberg, G.A.; Boom, J.A.; Szilagyi, P.G.; et al. Epidemiologic association between FUT2 secretor status and severe rotavirus gastroenteritis in children in the united states. JAMA Pediatrics 2015, 169, 1040-1045.

24. Zhang, X.F.; Long, Y.; Tan, M.; Zhang, T.; Huang, Q.; Jiang, X.; Tan, W.F.; Li, J.D.; Hu, G.F.; Tang, S.; et al. P[8] and $\mathrm{P}[4]$ rotavirus infection associated with secretor phenotypes among children in south China. Sci. Rep. 2016, 6, 34591. [CrossRef] [PubMed]

25. Pérez-Ortín, R.; Vila-Vicent, S.; Carmona-Vicente, N.; Santiso-Bellón, C.; Rodríguez-Díaz, J.; Buesa, J. Histoblood group antigens in children with symptomatic rotavirus infection. Viruses 2019, 11, 339. [CrossRef] [PubMed]

26. Ayouni, S.; Sdiri-Loulizi, K.; de Rougemont, A.; Estienney, M.; Ambert-Balay, K.; Aho, S.; Hamami, S.; Aouni, M.; Neji-Guediche, M.; Pothier, P.; et al. Rotavirus P[8] infections in persons with secretor and nonsecretor phenotypes, tunisia. Emerg. Infect. Dis. 2015, 21, 2055-2058. [CrossRef] [PubMed]

27. Lee, B.; Dickson, D.M.; de Camp, A.C.; Ross Colgate, E.; Diehl, S.A.; Uddin, M.I.; Sharmin, S.; Islam, S.; Bhuiyan, T.R.; Alam, M.; et al. Histo-blood group antigen phenotype determines susceptibility to genotypespecific rotavirus infections and impacts measures of rotavirus vaccine efficacy. J. Infect. Dis. 2018, 217, 1399-1407. [CrossRef] [PubMed]

28. Vicentini, F.; Denadai, W.; Gomes, Y.M.; Rose, T.L.; Ferreira, M.S.; Le Moullac-Vaidye, B.; Le Pendu, J.; Leite, J.P.; Miagostovich, M.P.; Spano, L.C. Molecular characterization of noroviruses and HBGA from infected quilombola children in espirito santo state, Brazil. PLoS ONE 2013, 8, e69348. [CrossRef]

29. Cantelli, C.P.; Fumian, T.M.; Malta, F.C.; da Cunha, D.C.; Brasil, P.; Nordgren, J.; Svensson, L.; Miagostovich, M.P.; de Moraes, M.; Leite, J. Norovirus infection and HBGA host genetic susceptibility in a birth community-cohort, rio de janeiro, Brazil. Infect. Genet. Evol. 2020, 82, 104280. [CrossRef]

30. World Health Organization. The Treatment of Diarrhoea: A Manual for Physicians and Other Senior Health Workers. Available online: https://apps.who.int/iris/handle/10665/43209 (accessed on 25 February 2020).

31. Fumian, T.M.; de Andrade, J.S.R.; Leite, J.P.G.; Miagostovich, M.P. Norovirus recombinant strains isolated from gastroenteritis outbreaks in southern Brazil 2004-2011. PLoS ONE 2016, 11, e0145391. [CrossRef]

32. Kageyama, T.; Kojima, S.; Shinohara, M.; Uchida, K.; Fukushi, S.; Hoshino, F.B.; Takeda, N.; Katayama, K. Broadly reactive and highly sensitive assay for norwalk-like viruses based on real-time quantitative reverse transcription-PCR. J. Clin. Microbiol. 2003, 41, 1548-1557. [CrossRef]

33. Zeng, S.Q.; Halkosalo, A.; Salminen, M.; Szakal, E.D.; Puustinen, L.; Vesikari, T. One-step quantitative RT-PCR for the detection of rotavirus in acute gastroenteritis. J. Virol. Methods 2008, 153, 238-240. [CrossRef]

34. Gentsch, J.R.; Glass, R.I.; Woods, P.; Gouvea, V.; Gorziglia, M.; Flores, J.; Das, B.K.; Bhan, M.K. Identification of group a rotavirus gene 4 types by polymerase chain reaction. J. Clin. Microbiol. 1992, 30, 1365-1373. [CrossRef]

35. Beuret, C.; Kohler, D.; Baumgartner, A.; Lüthi, T.M. Norwalk-like virus sequences in mineral waters: One-year monitoring of three brands. Appl. Environ. Microbiol. 2002, 68, 1925-1931. [CrossRef] [PubMed]

36. Kojima, S.; Kageyama, T.; Fukushi, S.; Hoshino, F.B.; Shinohara, M.; Uchida, K.; Natori, K.; Takeda, N.; Katayama, K. Genogroup-specific PCR primers for detection of norwalk-like viruses. J. Virol. Methods 2002, 100, 107-114. [CrossRef] 
37. Kroneman, A.; Vennema, H.; Deforche, K.; v d Avoort, H.; Peñaranda, S.; Oberste, M.S.; Vinjé, J.; Koopmans, M. An automated genotyping tool for enteroviruses and noroviruses. J. Clin. Virol. 2011, 51, 121-125. [CrossRef] [PubMed]

38. Barreira, D.; Fumian, T.M.; Tonini, M.; Volpini, L.; Santos, R.P.; Ribeiro, A.; Leite, J.; Souza, M.; Brasil, P.; da Cunha, D.C.; et al. Detection and molecular characterization of the novel recombinant norovirus GII.P16-GII.4 Sydney in southeastern Brazil in 2016. PLoS ONE 2017, 12, e0189504. [CrossRef]

39. Marionneau, S.; Airaud, F.; Bovin, N.V.; Le Pendu, J.; Ruvoën-Clouet, N. Influence of the combined ABO, FUT2, and FUT3 polymorphism on susceptibility to norwalk virus attachment. J. Infect. Dis. 2005, 192, 1071-1077.

40. Grahn, A.; Elmgren, A.; Aberg, L.; Svensson, L.; Jansson, P.A.; Lönnroth, P.; Larson, G. Determination of lewis FUT3 gene mutations by PCR using sequence-specific primers enables efficient genotyping of clinical samples. Hum. Mutat. 2001, 18, 358-359.

41. Procter, J.; Crawford, J.; Bunce, M.; Welsh, K.I. A rapid molecular method (polymerase chain reaction with sequence-specific primers) to genotype for $\mathrm{ABO}$ blood group and secretor status and its potential for organ transplants. Tissue Antigens 1997, 50, 475-483. [CrossRef]

42. Günaydın, G.; Nordgren, J.; Sharma, S.; Hammarström, L. Association of elevated rotavirus-specific antibody titers with HBGA secretor status in Swedish individuals: The FUT2 gene as a putative susceptibility determinant for infection. Virus Res. 2016, 211, 64-68. [CrossRef]

43. Armah, G.E.; Cortese, M.M.; Dennis, F.E.; Yu, Y.; Morrow, A.L.; McNeal, M.M.; Lewis, K.; Awuni, D.A.; Armachie, J.; Parashar, U.D. Rotavirus vaccine take in infants is associated with secretor status. J. Infect. Dis. 2019, 219, 746-749. [CrossRef]

44. Bucardo, F.; Reyes, Y.; Rönnelid, Y.; González, F.; Sharma, S.; Svensson, L.; Nordgren, J. Histo-blood group antigens and rotavirus vaccine shedding in nicaraguan infants. Sci. Rep. 2019, 9, 10764. [CrossRef]

45. Zeller, M.; Heylen, E.; Damanka, S.; Pietsch, C.; Donato, C.; Tamura, T.; Kulkarni, R.; Arora, R.; Cunliffe, N.; Maunula, L. Emerging OP354-Like P[8] rotaviruses have rapidly dispersed from asia to other continents. Mol. Biol. Evol. 2015, 32, 2060-2071. [CrossRef] [PubMed]

46. Khachou, A.; Le Moullac-Vaidye, B.; Peltier, C.; Breiman, A.; Imbert-Marcille, B.M.; Ruvoen-Clouet, N.; Aouni, M.; Mastouri, M.; Chouchane, S.; Le Pendu, J. Host-range shift between emerging P[8]-4 rotavirus and common P[8] and P[4] strains. J. Infect. Dis. 2020, 222. [CrossRef] [PubMed]

47. Carvalho-Costa, F.A.; de Assis, R.; Fialho, A.M.; Araújo, I.T.; Silva, M.F.; Gómez, M.M.; Andrade, J.S.; Rose, T.L.; Fumian, T.M.; Volotão, E.M.; et al. The evolving epidemiology of rotavirus a infection in Brazil a decade after the introduction of universal vaccination with Rotarix ${ }^{\circledR}$. BMC Pediatrics 2019, 19, 42. [CrossRef] [PubMed]

48. Ma, X.; Li, D.D.; Sun, X.M.; Guo, Y.Q.; Xiang, J.Y.; Wang, W.H.; Zhang, L.X.; Gu, Q.J.; Duan, Z.J. Binding patterns of rotavirus genotypes $\mathrm{P}[4], \mathrm{P}[6]$, and $\mathrm{P}[8]$ in China with histo-blood group antigens. PLoS ONE 2015, 10, e0134584. [CrossRef] [PubMed]

49. Bernardo, C.R.; Camargo, A.; Ronchi, L.S.; de Oliveira, A.P.; de Campos Júnior, E.; Borim, A.A.; Brandão de Mattos, C.C.; Bestetti, R.B.; de Mattos, L.C. ABO, secretor and lewis histo-blood group systems influence the digestive form of chagas disease. Infect. Genet. Evol. 2016, 45, 170-175. [CrossRef]

50. de Moraes, M.; Olivares, A.; Fialho, A.M.; Malta, F.C.; da Silva, E.; Mouta Junior, S.; de Souza Bispo, R.; Velloso, A.J.; Alves Leitão, G.A.; Cantelli, C.P.; et al. Phenotyping of lewis and secretor HBGA from saliva and detection of new FUT2 gene SNPs from young children from the amazon presenting acute gastroenteritis and respiratory infection. Infect. Genet. Evol. 2019, 70, 61-66. [CrossRef]

51. Nakashima, F.; Brandão de Mattos, C.C.; Ferreira, A.; Spergiorin, L.; Meira-Strejevitch, C.S.; Oliani, A.H.; Vaz-Oliani, D.; Pereira-Chioccola, V.L.; de Mattos, L.C. FUT3 and FUT2 genotyping and glycoconjugate profile Lewis b as a protective factor to toxoplasma gondii infection. Acta Trop. 2019, 193, 92-98. [CrossRef]

52. Kazi, A.M.; Cortese, M.M.; Yu, Y.; Lopman, B.; Morrow, A.L.; Fleming, J.A.; McNeal, M.M.; Steele, A.D.; Parashar, U.D.; Zaidi, A.; et al. Secretor and salivary ABO blood group antigen status predict rotavirus vaccine take in infants. J. Infect. Dis. 2017, 215, 786-789. [CrossRef]

53. Bucardo, F.; Nordgren, J.; Reyes, Y.; Gonzalez, F.; Sharma, S.; Svensson, L. The Lewis a phenotype is a restriction factor for rotateq and rotarix vaccine-take in nicaraguan children. Sci. Rep. 2018, 8, 1502. [CrossRef] 
54. Cantelli, C.P.; Velloso, A.J.; Assis, R.; Barros, J.J.; Mello, F.; Cunha, D.; Brasil, P.; Nordgren, J.; Svensson, L.; Miagostovich, M.P.; et al. Rotavirus a shedding and HBGA host genetic susceptibility in a birth communitycohort, rio de janeiro, Brazil, 2014-2018. Sci. Rep. 2020, 10. [CrossRef]

55. Nordgren, J.; Nitiema, L.W.; Ouermi, D.; Simpore, J.; Svensson, L. Host genetic factors affect susceptibility to norovirus infections in burkina faso. PLoS ONE 2013, 8, e69557. [CrossRef] [PubMed]

56. Liu, P.; Wang, X.; Lee, J.C.; Teunis, P.; Hu, S.; Paradise, H.T.; Moe, C. Genetic susceptibility to norovirus GII.3 and GII.4 infections in Chinese pediatric diarrheal disease. Pediatrics Infect. Dis. 2014, 33, 305-309. [CrossRef] [PubMed]

57. Lopman, B.A.; Trivedi, T.; Vicuña, Y.; Costantini, V.; Collins, N.; Gregoricus, N.; Parashar, U.; Sandoval, C.; Broncano, N.; Vaca, M. Norovirus infection and disease in an ecuadorian birth cohort: Association of certain norovirus genotypes with host FUT2 secretor status. J. Infect. Dis. 2015, 211, 1813-1821. [CrossRef]

58. Bucardo, F.; Kindberg, E.; Paniagua, M.; Grahn, A.; Larson, G.; Vildevall, M.; Svensson, L. Genetic susceptibility to symptomatic norovirus infection in Nicaragua. J. Med. Virol. 2009, 81, 728-735. [CrossRef] [PubMed]

59. de Rougemont, A.; Ruvoen-Clouet, N.; Simon, B.; Estienney, M.; Elie-Caille, C.; Aho, S.; Pothier, P.; Le Pendu, J.; Boireau, W.; Belliot, G. Qualitative and quantitative analysis of the binding of GII.4 norovirus variants onto human blood group antigens. J. Virol. 2011, 85, 4057-4070. [CrossRef] [PubMed]

60. Lindesmith, L.; Moe, C.; Le Pendu, J.; Frelinger, J.A.; Treanor, J.; Baric, R.S. Cellular and humoral immunity following Snow Mountain virus challenge. J. Virol. 2005, 79, 2900-2909. [CrossRef]

61. Jin, M.; He, Y.; Li, H.; Huang, P.; Zhong, W.; Yang, H.; Zhang, H.; Tan, M.; Duan, Z.J. Two gastroenteritis outbreaks caused by GII noroviruses: Host susceptibility and HBGA phenotypes. PLoS ONE 2013, 8, e58605. [CrossRef]

62. Barbé, L.; Le Moullac-Vaidye, B.; Echasserieau, K.; Bernardeau, K.; Carton, T.; Bovin, N.; Nordgren, J.; Svensson, L.; Ruvoën-Clouet, N.; Le Pendu, J. Histo-blood group antigen-binding specificities of human rotaviruses are associated with gastroenteritis but not with in vitro infection. Sci. Rep. 2018, 8, 1-14. [CrossRef]

63. Gozalbo-Rovira, R.; Ciges-Tomas, J.R.; Vila-Vicent, S.; Buesa, J.; Santiso-Bellón, C.; Monedero, V.; Yebra, M.J.; Marina, A.; Rodríguez-Díaz, J. Unraveling the role of the secretor antigen in human rotavirus attachment to histo-blood group antigens. PLoS Pathog. 2019, 15, e1007856. [CrossRef]

64. Sun, X.; Dang, L.; Li, D.; Qi, J.; Wang, M.; Chai, W.; Zhang, Q.; Wang, H.; Bai, R.; Tan, M.; et al. Structural basis of glycan recognition in globally predominant human P[8] rotavirus. Virol. Sin. 2019, 35, 156-170. [CrossRef]

65. Xu, S.; Ahmed, L.U.; Stuckert, M.R.; McGinnis, K.R.; Liu, Y.; Tan, M.; Huang, P.; Zhong, W.; Zhao, D.; Jiang, X.; et al. Molecular basis of $\mathrm{P}[\mathrm{II}]$ major human rotavirus VP8* domain recognition of histo-blood group antigens. PLoS Pathog. 2020, 16, e1008386. [CrossRef] [PubMed]

66. Larsson, M.M.; Rydell, G.E.; Grahn, A.; Rodriguez-Diaz, J.; Akerlind, B.; Hutson, A.M.; Estes, M.K.; Larson, G.; Svensson, L. Antibody prevalence and titer to norovirus (genogroup II) correlate with secretor (FUT2) but not with ABO phenotype or Lewis (FUT3) genotype. J. Infect. Dis. 2006, 194, 1422-1427. [CrossRef] [PubMed]

67. Tu, L.T.; Liu, F.P.; Huang, Y.C.; Huang, C.G.; Yang, S.; Tsao, K.C.; Lai, M.W.; Chen, C.J. Genetic susceptibility to norovirus GII.4 sydney strain infections in Taiwanese children. Pediatrics Infect. Dis. J. 2017, 36, 353-357. [CrossRef] [PubMed]

68. Kubota, T.; Kumagai, A.; Ito, H.; Furukawa, S.; Someya, Y.; Takeda, N.; Ishii, K.; Wakita, T.; Narimatsu, H.; Shirato, H. Structural basis for the recognition of lewis antigens by genogroup i norovirus. J. Virol. 2012, 86, 11138-11150. [CrossRef]

69. Serpa, J.; Almeida, R.; Oliveira, C.; Silva, F.S.; Silva, E.; Reis, C.; Le Pendu, J.; Oliveira, G.; Ribeiro, L.M.; David, L. Lewis enzyme (alpha1-3/4 fucosyltransferase) polymorphisms do not explain the lewis phenotype in the gastric mucosa of a Portuguese population. J. Hum. Genet. 2003, 48, 183-189. [CrossRef]

70. Torrado, J.; Ruiz, B.; Garay, J.; Cosme, A.; Arenas, J.I.; Bravo, J.C.; Fontham, E.; Correa, P. Lewis, secretor, and ABO phenotypes, and sulfomucin expression in gastric intestinal metaplasia. Cancer Epidemiol. Biomark. Prev. 1997, 6, 287-289.

71. Corvelo, T.C.; de Loiola, R.; Aguiar, D.C.; de Matos, G.; de Brito, D.C. The Lewis histo-blood group system: Molecular analysis of the 59T>G,508G $>$ A, and 1067T >A polymorphisms in an Amazonian population. PLoS ONE 2013, 8, e69908. [CrossRef] 
72. Nishihara, S.; Narimatsu, H.; Iwasaki, H.; Yazawa, S.; Akamatsu, S.; Ando, T.; Seno, T.; Narimatsu, I. Molecular genetic analysis of the human lewis histo-blood group system. J. Biol. Chem. 1994, 269, 29271-29278.

73. Soejima, M.; Kimura, H.; Koda, Y. Two novel FUT3 alleles responsible for lewis-null phenotypes in Sri Lanka. Transfusion 2004, 44, 1534-1535. [CrossRef]

74. Soejima, M.; Munkhtulga, L.; Iwamoto, S.; Koda, Y. Genetic variation of FUT3 in ghanaians, caucasians, and mongolians. Transfusion 2009, 49, 959-966. [CrossRef]

(c) (P)

(C) 2020 by the authors. Licensee MDPI, Basel, Switzerland. This article is an open access article distributed under the terms and conditions of the Creative Commons Attribution (CC BY) license (http://creativecommons.org/licenses/by/4.0/). 